\title{
The Evolution of Earth Federation from a Cosmic Perspective
}

\author{
Chris Hamer \\ University of New South Wales, Australia \\ World Citizens Association of Australia \\ Coalition for a World Security Community
}

\begin{abstract}
From a cosmic perspective, we are all citizens of the one small and lonely planet Earth, and we all face some major global challenges. Some of them may even threaten the future of our civilization, such as climate change and nuclear weapons, to name but two. These critical global problems need global solutions, and we need to work together to find solutions to them. Ideally, we need some form of Earth Federation, empowered to make binding laws and regulations to deal with these global issues. I will trace the history of the world federation concept, and discuss how it might be put into practice. Post-war efforts have always concentrated on reform of the United Nations, only to be stymied by the rigidity of the UN Charter. Meanwhile, Europe has shown the way, with the stage-by-stage evolution of the European Union, and has developed the basic principles upon which the Earth Federation should be based. I will discuss a possible alternative route to the goal, which follows the European example. A detailed discussion of a possible first step is discussed. It is suggested that the North Atlantic Treaty Organization be reformed to accept membership from democratic countries outside the North Atlantic area, to become a World Security Community of democratic nations. It could act as a strong right arm to the Security Council on the world stage. Such a community would form a natural starting point for the evolution over time of a genuine global parliament.
\end{abstract}

Key words: Earth Federation, world federation, global parliament, world security community, NATO.

Correspondence | Chris Hamer, C.Hamer@unsw.edu.au

Citation | Hamer, C. (2019) The Evolution of Earth Federation from a Cosmic Perspective. Journal of Big History, III(3); 191 - 203.

DOI | https://doi.org/10.22339/jbh.v3i3.3311

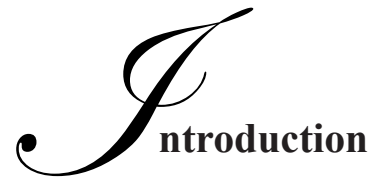

All human beings, regardless of their nationality, have many fundamental interests in common, and face some enormous common problems, such as:

- Global warming and other forms of damage to the environment have become an alarming new threat to our children's heritage. This could be humanity's greatest challenge.

- Seventy years after World War II, mankind still faces a looming threat from nuclear weapons. There are still many thousands of nuclear warheads in existence, and if they all went off they could literally destroy human civilisation as we know it.

- Conflicts and wars have displaced around 69 million people, a number greater than the entire population of France, forced to abandon their homes or become refugees.

- Billions of the world's poor still face the ever- 
present dangers of famine, disease and war. Each day, to our shame, many thousands of children still die needlessly.

- The basic human rights of many thousands of people are trampled on every day, without means of redress.

These global problems require global solutions. They can only be resolved if the peoples of the world work together to construct a system of binding international law and democratic global governance, which ideally should be based upon a democratically elected global parliament, or Earth Federation. The present United Nations is not adequate to the task. A recent article by Luis Cabrera (2017) has emphasized this conclusion anew, focusing particularly on the human rights aspect.

From a cosmic perspective, these conclusions seem obvious (Sagan 1994, White 2014), as emphasized in an inspiring recent article by Ian Crawford (2017). Several of the astronauts have commented, looking back at the Earth, that the artificial boundaries between nation-states are invisible from space. Rusty Schweickart, for example, said:

"You look down there and you can't imagine how many borders and boundaries you cross, again and again and again, and you don't even see them. There you are - hundreds of people in the Mid-East killing each other over some imaginary lines that you're not even aware of ... And from where you see it the thing is a whole, and it's so beautiful. You wish you could take one in each hand, one from each side in the various conflicts, and say 'Look, look at it from this perspective..."”

(Schweickart 1977)

According to the popular TV and film series Star Trek, United Earth, also known as the World Government, was a planetary state created through the unification of Earth in the 22nd century, following First Contact with Vulcans in 2063. United Earth continued to exist as a member world of the United Federation of Planets when Earth helped found that interstellar state in 2161. From a cosmic perspective, it would be inconceivable that we should not speak with one voice in our first contacts with extraterrestrial beings, or try to export our petty and parochial national disputes and conflicts into space. Adlai Stevenson once commented:

"We can never again be a squabbling band of nations before the awful majesty of outer space."

(Stevenson 1965)

An earlier proponent was H.G. Wells, the godfather of 'Big History' in his attempt at a history of the whole planet, "The Outline of History" (1922). He was also a prophet of world government, with two books, "The World Set Free" (1914), and "The Shape of Things to Come" (1933). In a forceful summary of his beliefs, he wrote:

"There can be little question that the attainment of a federation of all humanity, together with a sufficient measure of social justice, to ensure health, education, and a rough measure of equality of opportunity to most of the children born into the world, would mean such a release and increase of human energy as to open a new phase in human history."

(Wells 1922)

Albert Einstein was also a world federalist, and spent much of the last ten years of his life arguing tirelessly for world government, co-authoring the Russell-Einstein manifesto, for instance. One of his famous quotes is:

"In my opinion the only salvation for civilization and the human race lies in the creation of a world government, with security of nations founded upon law. As long as sovereign states continue to have separate armaments and armament secrets, new world wars will be inevitable." (quoted in Nathan and Nordern 1968) 
The objectives of an Earth Federation would include:

- "To save succeeding generations from the scourge of war", i.e. to end all wars, and finally get rid of nuclear weapons;

- To preserve the global environment, and halt climate change;

- To guarantee fundamental human rights;

- To establish a system of binding international law;

- "To promote social progress and better standards of life in larger freedom."

In other words, the same aims as the United Nations, which has not been strong enough to achieve them!

The more difficult question is, how do we get there from here? World federalists have been grappling with this problem ever since World War II. The history of the world federalist movement is recounted, for instance, in books by Joseph Baratta (2004), and a recent detailed and in-depth discussion by Leinen and Bummel (2018). Uniting seven billion people in nearly two hundred countries - each jealous of its sovereignty - is an enormous task. Like climbing Mount Everest, it will not be achieved in a single giant bound. We will only get there gradually, through a series of base camps. In the Schuman Declaration (1950), the founding document of the European Union, it is stated for example that "Europe will not be built in a day, or according to a single plan." The same applies to the global system of governance.

\section{Principles of an Earth Federation}

It is probably more useful to set out the principles upon which a global parliament should be based (Hamer 1998), rather than try to specify the detailed form or structure it might eventually take. For these principles we rely heavily on the lessons learnt in the construction of the European Union. The preamble to the Maastricht Treaty (1992) mentions some important principles, although it gives no detailed exposition of them. It includes obvious principles like the rule of law, and respect for human rights. The Treaty also includes important new principles needed for the integration of the diverse European nations, such as:

Solidarity. Equity demands that all citizens be accorded equal rights and equal opportunities under the law, regardless of race, religion, gender or ethnicity. Hence springs the European policy of structural development funds, to bring the more economically backward member states up to speed with the others.

Subsidiarity. Decisions must be made as closely as possible to the individual citizens, to allow them to participate fully in the political process. This implies a multi-layered system of government in which local councils look after local affairs, and national governments retain sovereignty over their own internal affairs very much as they do at present. Only those matters which cannot be dealt with by a single nation acting alone become the province of the European parliament. This implies a federal system of government. Both of these principles would apply equally well to a future global parliament. Finally, there are two more important principles, which unfortunately are not mutually compatible at the global level at present. They are:

Democracy. To guard against autocracy and abuse of power, and to preserve the liberty and equality of all its citizens, the government must be chosen by means of free and fair elections, with guaranteed freedom of organized groups to stand in opposition to the government in power. Democracy is the only form of government with a 'safety valve', whereby the people can replace the government if it is doing a bad job.

Universality. Finally, if the global parliament is to deal successfully with global problems, it must in- 
clude all of the world's nations, as the United Nations in essence already does. Universality was announced as the first principle of world federation at the great Montreux Congress of 1947 (Montreux 1947).

There is a major difficulty here, however, in that the principles of democracy and universality are not mutually compatible at present. Not all nations are democratic. The Freedom House group in the United States carries out a yearly rating of countries around the globe, based on a combination of political factors and civil liberties. They estimated in 2015 that 89 states were "free", 55 states were "partly free", and 51 states were "not free" (Freedom House 2015). In other words, less than half of all nations are fully democratic at present.

Could a global parliament include non-democratic states, putting the principle of universality first, or do we have to wait until all states become democratic, putting democracy first? We address this question in the next section. Suffice it to say that a fully-functioning global parliament including non-democratic states would involve intolerable anomalies, such as the violation of human rights under autocratic governments.

\section{Pathways to an Earth Federation}

There are some enormous obstacles to be overcome in the construction of a global parliament. The realist Hans Morgenthau, for instance, wrote in 1948 that:

\footnotetext{
"The argument of the advocates of the world state is unanswerable. There can be no permanent international peace without a state coextensive with the confines of the political world." $\mathrm{He}$ argues, however, that such a world state is simply not feasible: "No society exists coextensive with the presumed range of a world state. The nation is the recipient of man's highest secular loyalties. Beyond it there are other nations, but no community for which man would be willing to act regardless of what he understands the interests
}

of his own nation to be. In other words, the people of the world are not ready to accept world government, and their overriding loyalty to their own nation erects an insurmountable obstacle to its establishment."

(Morgenthau 1973)

Times have changed since Morgenthau wrote these lines at the beginning of the Cold War, but nevertheless he correctly identifies the major roadblock to a world government.

So what then is the most likely route towards the ultimate goal of a global parliament? At least four possible routes have been identified (DWF).

\section{a) Create a World Constitution.}

According to this idea, we should immediately hold an international Convention to hammer out a Constitution for the proposed world federation, and then put it into practice, as at the founding of the United States. This is the strategy espoused by the World Constitution and Parliamentary Association, among many others.

The problem here is that the strategy presupposes general agreement that a world federation is necessary and desirable. That is unfortunately not the case, and a referendum would most likely show that only a few percent of the general public would say that we are ready for a world federation at present. A Constitutional Convention should be the last step in the integration process, not the first, and is hardly feasible at present in my view.

\section{b) Integrate the Regions}

According to this strategy, we should first concentrate on integrating the regions, following the European example, and then integrate the regions to form a world federation. The European federalists decided to concentrate on their own regional integration after the great Montreux Congress in 1947, and since then the evolution of the European Union has been emulated 
by organisations such as the African Union and the South American union UNASUR, although the latter still remains largely on the drawing-board.

This strategy may succeed eventually, but it would be a long and difficult route, very hard to predict in detail. There are many fledgling regional organisations around the globe, but they are not developing very rapidly. The European Union itself is in some danger of unravelling at present, following Brexit. It would probably be better to work on parallel strategies which might reach the goal more quickly.

\section{c) Transform the United Nations}

The strategy here is to reform the United Nations, the peak global organisation we have at present, to become a genuine world federation. The present United Nations is far too weak to deal effectively with the global problems that beset us. We shall not enter here into the manifold shortcomings of the organisation. In essence, it follows a pattern dating back to the Congress of Vienna after Waterloo: an alliance of the great powers (the P5 in the Security Council) to keep the peace.

This is the most obvious strategy to follow, and it is the one which the world federalist movement (WFM-IGP) has concentrated on for seventy years, ever since World War II (Baratta 2004, Leinen and Bummel 2018). But always the campaign has run up against the great obstacle of the UN Charter. It is very difficult to amend, similar to a national constitution. It requires two-thirds of the member states and all five permanent members of the Security Council to approve any amendment. This is so hard to achieve, in fact, that no meaningful change has ever been made to the Charter. No Charter Review Conference has even been convened.

In these circumstances, the WFM-IGP has lowered its sights in recent years, and concentrated on reforms which do not require any change in the Charter.
There they have had some very important successes. They have convened Coalitions of non-government organisations to campaign firstly, for an International Criminal Court, and secondly, for the doctrine of Responsibility to Protect. Both those campaigns have succeeded, and bolstered the structure of international law very significantly. But they do not address the structural problems of the UN organisation itself.

The most lively new initiative along this route is the Campaign for a United Nations Parliamentary Assembly (UNPA), which aims to inject at least an element of democratically elected parliamentary representation into the $\mathrm{UN}$ system. This campaign is led by its Global Coordinator, Andreas Bummel (see Leinen and Bummel 2018).

Nevertheless, the UN Charter presents a very daunting obstacle along this route. Broadly speaking, everybody agrees that the UN needs reform, but no two nations can agree on what those reforms should be. We should keep pushing along this route, but the prospects appear rather dim at present.

\section{d) Unite the Democracies}

This brings us to the final strategy, which is to begin by integrating the democratic nations first, and then bring in other nations later, as they adopt more democratic forms of government. This strategy emphasizes the principle of democracy before that of universality. An early proponent was Clarence Streit. In the final postwar edition of his book 'Union Now!' (Streit 1939), he advocated a union of democracies as a first step towards an eventual world federation. The Streit Council continues to advocate a union of democratic nations today.

This is the strategy most likely to succeed, in our opinion. There is no rigid Charter in the way, so change can proceed in an evolutionary fashion following the European example. We could start with an association with strictly limited aims linking some of the more 
progressive nations - i.e. the democracies - and then build from there, progressively expanding functions, developing institutions, and including more members, until a democratic Earth Federation is eventually achieved.

\section{The European example}

Historically, there have been calls for European integration over some 600 years (Hamer 1998, Baratta 2004), For example, William Penn called for a European Parliament in 1692, George Washington predicted the creation of a United States of Europe after the foundation of the United States of America (Millard 1969), and Victor Hugo gave a slashing speech calling for the same objective at the first Paris Peace Conference in 1849.

Then came World War II, which was the fifth major war between France and Germany in 200 years, and resulted in around 55 million dead, or about $3 \%$ of the entire world's population at the time! Leaders in Europe determined that it must never happen again, and recognized that integration between the nations of Europe was the way to prevent it.

Jean Monnet and his colleagues, such as Robert Schuman, Konrad Adenauer, Paul-Henri Spaak, Alcide De Gasperi and Altieri Spinelli, devised an effective strategy. They started with a smaller group of 'progressive' states (the 'Six'), and established a community with a limited aim to unite the coal and steel industries of Europe, in the form of the European Coal and Steel Community. They then evolved stepby-step through a series of Treaties to build first the European Economic Community, and finally the present European Union and European Parliament, which now embraces twenty-eight nation-states and nearly 500 million inhabitants.

Their ultimate aim of a European Federation has still not been achieved in full, and the EU is going through some severe trials and tribulations at the present time (e.g. Brexit), but the great original objective is now secure. There will never again be a war between France and Germany.

The question then arises, can we do something similar at the global level? The first step would seem to be the formation of a community on the European model, rather than the more ambitious target of a union or federation. Hence we are led to propose a world community of democratic nations.

Now we come to what is likely to be a much more contentious question, namely, what should be the basis or purpose of such a community? Ideally, it should be economic, and have a strong impact on the daily life of the community in order to attract new members, following the European model. But there seems little call at present for a community based on free trade, like the EEC. The world has been pursuing free trade agreements ever since World War II, and the last Doha Round ended in failure. At present, the nations are mostly pursuing bilateral rather than multilateral agreements.

At the present time, there is a much more obvious need for a community based on common security, a world security community of democracies. The US tried for a time recently to act as 'global policeman' on its own, and has had its fingers severely burnt in most cases. It led interventions in Afghanistan, Iraq, Libya and Syria which cost huge amounts of money and left chaos behind them, as witness the present maelstrom in the Middle East. It is now widely recognized that the US needs to work much more closely with its democratic friends and allies. Hence the formation of a security community made up of the democracies would be a natural next step. Such a community would provide a virtually unchallengeable guarantee of security for its members, and could also provide a strong right arm for the United Nations in security and peacekeeping missions in the wider world. 
In the following we will discuss a more detailed proposal of this type. It is proposed that NATO and the OECD should be reconstituted as two arms of a new World Security Community of democratic nations.

\section{Proposal and Objectives}

The proposal then consists of the following basic elements:

- Refocus NATO to give it a global mission, first to guarantee the security and freedom of all its members, and then to act as their security and peacekeeping arm in the wider world, under the aegis of the UN.

- Open membership to stable democracies outside North America and Europe, e.g. Japan, South Korea, Australia, and New Zealand. Eventually membership of the Community should be opened to any stable, democratic nation, subject to suitable criteria laid down by the existing member states. In the long run, it is envisaged that the organization will become universal, as democracy spreads to the rest of the globe;

- An explicit declaration should be made that the new community will only intervene forcibly in external states if authorized to do so by the UN Security Council, in accordance with international law;

- Alter the dysfunctional decision-making system within NATO, preferably at all levels, to a 'qualified-majority voting with opt-out' system, as advocated previously by a group of senior military men, all former chiefs of staff in their respective countries (Jones 2007, Naumann et al. 2007). To avoid indecision and deadlock, decisions on functional matters within the agreed competence of the organization should be made by some form of qualified-majority voting - unlike the consensus which is customarily required in NATO today. Such a scheme has been used by the European
Union. This would transform the alliance into a 'security community', which might be named the World Security Community of democratic nations.

- Channel funds to foster development in the more backward member states under the principle of "solidarity" established by the European Union. This would promote a feeling of community among the member states, and provide a strong incentive for new states to join in. This function could perhaps be undertaken by adding in the OECD, which has a very similar membership, as a second arm of the community.

- Restructure the organization with appropriate organs of democratic governance, following the pattern established by the European Union:

- A North Atlantic Council already exists, representing the member states. Instead of consensus decision-making, it should adopt a 'qualified majority' voting system, as above.

- A NATO Parliamentary Assembly already exists, as the basis for a democratic chamber, but its official recognition is low;

- A Court needs to be established, to settle differences over the interpretation of the founding treaty, and settle disputes between the member states on the basis of international law. This would form the embryo of an eventual legal system;

- A bureaucracy in Brussels already exists, headed by the Secretary-General, and the regular budget of NATO is about $\$ 6$ billion per annum, which is already larger than the UN core budget.

Such an association would be much more flexible than the UN, able to change and grow through successive treaties, and could indeed form the nucleus for an eventual system of democratic global governance. 


\section{Benefits}

The Community could evolve over time, following the European example, into a full-blown Earth Federation or global parliament. Meanwhile, the Community would bring some major benefits in terms of global peace and security.

Firstly, it would provide a virtually ironclad guarantee against external attack for its expanded and growing list of members. It would enable them to share the burden and the responsibility, and pool their resources, in carrying out peacebuilding and security operations on the world stage. It would also provide a new legal framework for settling international disputes between members in a peaceful fashion.

It would cure the dysfunctional decision-making procedure presently operative within NATO, as has been recommended in the past by senior military men (Jones 2007, Naumann et al. 2007). It would also give NATO (and possibly the OECD) an extended and hugely important mission for the future.

Acting in tandem with the UN, the new Community could bring important benefits to the wider world community. Acting strictly at the behest of the Security Council, the Community would provide a powerful means of enforcement for the resolutions of the Council. It could play a role very like that originally envisaged for a standing security force under Article 47 of the UN Charter. It would only intervene in an external state if authorized to do so by the Council; but conversely, like its member states, it would be obliged to lend support to any security enforcement actions which were in fact mandated by the Security Council, under article 43 of the Charter. It would thus provide a strong right arm to back up any security actions of the UN.

Furthermore, the new Community could quite easily set up rapid reaction units to carry out the role advocated for UNEPS, the proposed UN Emergency Peace Service. It could and should also set up mechanisms to prevent future conflicts, and to reconstruct failed states after conflict, in conjunction with the new Peacebuilding Commission at the UN. This would follow the outstanding example of the Marshall Plan after World War II. It would give the new Community a very positive role to play in healing the wounds created by armed conflict, something conspicuously absent after the recent overthrow of regimes in Iraq and Libya.

Thus the UN and the Community together would make up a greatly strengthened and more effective system of common security and international governance.

\section{Political considerations}

What is the likelihood of acceptance of such a scheme? Let us consider this question from various viewpoints.

\section{a) The United States}

One of the Republican contenders for the U.S. Presidency in 2008, John McCain, caused quite a stir when he proposed the formation of a 'League of Democracies' in order to build an enduring peace based on freedom (McCain 2007). "We Americans must be willing to listen to the collective will of our democratic allies," he said. On the Democratic side, Ivo Daalder, formerly the U.S. Permanent Representative on the Council of NATO, together with James Lindsay, proposed a 'Concert of Democracies' in order to form an "international institution capable of prompt and effective action both to prevent, and where necessary respond to threats to international security" (Daalder 2007). The idea of a Concert of Democracies was also promoted in an authoritative, bipartisan report from the Princeton Project (2006), “Forging a World of Liberty under Law”. So it seems 
there could be support for such ideas from both sides of politics in the U.S.

The main advantage for the US would be the opportunity to share with its partners the burden and responsibility of acting as 'global policeman', which no single nation has the right to assume in any case. In these times of financial stringency, the cost is a major consideration. In recent years, the astronomical cost of the wars in Iraq and Afghanistan, plus an expenditure on armaments roughly equivalent to the rest of the world put together, has taken a heavy toll on the US budget, so that the national debt now stands around $100 \%$ of GDP. Action to cut costs needs to be taken urgently, and sharing more of the security burden would help enormously. A move towards shared responsibility and collective security is clearly the right thing to do in any case.

The fact that spokesmen on both sides of US politics have advocated somewhat similar ideas indicates that a scheme of this sort should have a good chance of acceptance in the US, and if the US leads the way, the other members of NATO and the OECD are very likely to follow. The advent of the Trump administration has thrown all such calculations into doubt, of course, but President Trump has shown himself very keen to get the other members of NATO to shoulder more of the burden, and this scheme should help him to do that.

\section{b) Europe}

Europeans have already had long experience with transnational cooperation through the European Union. The Chancellor of Germany, Angela Merkel, is very much in favour of multilateral cooperation, as is the President of France, Emmanuel Macron. An ex-prime-minister of France, Edouard Balladur, has gone so far as to suggest a full union between the USA and Europe to deal with the full range of global foreign policy issues (Balladur 2007).
Despite this, the Europeans have apparently been very wary of the idea of a 'global NATO', being fearful of being dragged into neo-imperialist adventures under the dominance of the United States. These fears would be answered by an explicit declaration that the new Community would never use force to intervene in an external state unless authorized to do so by the Security Council, or else if it was itself under external attack. Furthermore, under a qualified majority voting scheme the US would have the largest voice, but by no means a dominant voice, in the councils of the Community. The introduction of qualified majority voting would give the Europeans a full voice in the decisions of the Community.

Very recently, debate has been revived in Europe as to whether a European army should be set up. Jean-Claude Juncker, the President of the European Commission, called for the EU to create a "common military force", including a command headquarters in Brussels. "We have to take responsibility for protecting ourselves and the European way of life", he said (Juncker 2016). Britain has always been firmly opposed to this idea, but now that the Brexit vote has taken place, this impediment has been removed. The Eastern Europeans are also opposed, being more concerned that the Atlantic alliance, i.e. NATO, should reinforce its presence in the East as bulwark against the perceived Russian threat. NATO has indeed agreed to station four battalions in the Baltic states and Eastern Poland (Stoltenberg 2016).

Establishment of the Community would probably settle the long-running debate as to whether Europe should build up its own armed forces for external defence. Europe would be able to rely on the Community for its external defence, and thereby save a considerable amount of money.

\section{c) Sweden}

Sweden is an example of a neutral state within 
Europe, and is not currently a member of NATO. There has been considerable internal debate, however, as to whether Sweden should in fact join NATO, and this has been fuelled recently by the revanchist behaviour of Russia. If NATO were to become a global security community, in conjunction with the UN, that might very well tip the balance and persuade neutral states such as Sweden to join the new organisation.

\section{d) Russia and China}

During the Cold War, the USSR looked on NATO with fear and suspicion, regarding it as a tool of the Western democracies and a threat to their very existence. Russia evidently continues to hold that viewpoint today. But if the new Community could only intervene externally when authorized by the Security Council to do so, then Russia would effectively have a veto over Community operations in the outside world. This should allay any Russian fears, especially when combined with the promise that they could eventually earn entry into the Community themselves. Similar remarks would apply to China, albeit to a lesser extent.

\section{Possible Problems}

\section{a) Polarization of the international community}

Non-member states of the new Community may feel excluded, and suspicious of the motives behind it. If the Community interfered in their affairs, they would feel resentful, and would tend to regard the Community as an "enemy", creating a split between "us" and "them". Such a polarization of the international community should be avoided at all costs.

Thus it would be important to make overtures to non-members, as the far-seeing Harmel Report recommended for NATO many years ago (Harmel 1967). It should be emphasized that membership of the Community is open to all countries, provided only that they satisfy suitable criteria for democratic governance and peaceful relations with their neighbours.

Furthermore, we have emphasized that the Community should guarantee never to undertake a military intervention in a non-member country, unless authorized to do so by the Security Council of the UN.

This might be a somewhat contentious issue in some quarters in the US, for instance, because it would place restrictions on the role the Community could play in serving US interests. It would even give Russia and China a veto over the external interventions of the Community. But in fact such a policy is obligatory under international law, as laid down in the UN Charter (Articles $2 \& 42$ ). It would also allay fears in Russia and China that the new Community was aimed against them.

\section{b) Conflict with the role of the UN}

A related problem is that the Community might be seen as competing with the role of the UN, in that both would be global security organizations. It will be vitally important to demonstrate that the Community would function in a manner complementary to the UN, rather than competing with it. Again, the Community should only intervene in a non-member state at the behest of the Security Council. The forces at the Community's disposal would then provide powerful reinforcement to the decisions of the Security Council. In fact, they would effectively supply the place of the standing armed forces originally envisaged for the UN under Article 47 of the Charter.

In summary, far from conflicting with the role of the UN, the new Community would fit in very neatly as the Security Council's strong right arm.

\section{c) Forcing 'Western' values on other cultures}

It might be charged that requiring democracy of new members is tantamount to forcing Western ideas 
of government onto what is meant to be a global community. But that is not a sustainable argument. Government "of the people, by the people, for the people" is a universal concept, not a purely Western one, and the thriving democracies in Japan and India are convincing examples of this. As more non-Western members join the Community, these fears should quickly be allayed.

\section{Conclusions}

In summary, the new Community would bring many benefits. It would cure some of the major problems within the present NATO system. It would produce a powerful new global security community, which acting in tandem with the Security Council would be a strong force for peace and freedom in the world.

Spokesmen on both sides of politics in the US have put forward similar schemes in the past, so there is a good chance that a plan of this sort would be acceptable to the USA. The Europeans would most likely be happy to follow, and so the proposal could have a realistic chance of being implemented.

If the Community is open to new members, subject to suitable criteria of democracy and peaceful relations with their neighbours, then one can envisage many new members joining up, attracted by the prospect of new structural development funds coming their way. The membership could soon include the majority of the world's nations, as more countries become democratic. Eventually, one may hope that membership in the Community would become universal.

With the addition of a Court, and the adoption of qualified majority voting, the association would become a community on the European model. It would provide a convenient forum for discussion and the making of common policy on matters beyond the security sphere, including trade, finance and the environment.
In time to come, one can envisage the Community evolving into a full-blown system of democratic global governance. That is "the light on the hill" for those of us who regard themselves as world citizens. From the cosmic perspective, as we reach for the stars we need to be able to speak with a single voice, and act together through a better and more effective system of global governance, one which will uphold the basic principles of democracy and human rights on the worldwide stage.

What could we do as global citizens to help implement this strategy? The world federalist movement WFM-IGP has found a successful strategy, forming large Coalitions of NGOs in support, first of all, of an International Criminal Court, and secondly, of the UN doctrine of Responsibility to Protect. Both of these campaigns achieved success in a relatively short time. Correspondingly, a new Coalition for a World Security Community of democratic nations (CWSC) is being set up as we speak.

\section{References}

Balladur Edouard 2007. Pour une Union occidentale entre l'Europe et les Etats-Unis Paris: Fayard

Baratta Joseph 2004. The Politics of World Federation. (two volumes), Westport Connecticut: Praeger.

Cabrera Luis 2017. 'Global government Revisited: From Utopian Vision to Political Imperative'. posted to the Great Transition Initiative (October 2017), see http://www.greattransition.org/ publication/global-government-revisited

Crawford Ian 2017. 'Space, World Government, and a 'Vast Future' for Humanity', The World Orders Forum (August 2017), see http://wgresearch.org/ space-world-government-vast-future-humanity/ 
CWSC. Coalition for a World Security Community of democratic nations, see http://coalitionforawsc. org/

Daalder Ivo and Lindsay James 2007. 'Democracies of the World, Unite' The American Interest 2, no. 3: 5-15. See https://onlinelibrary.wiley.com/doi/ abs/10.1111/j.1744-540X.2007.00465.X

DWF. Democratic World Federalists. See the website at http://www.dwfed.org/

Freedom House 2015. Annual report 'Freedom in the World'. see http://www.freedomhouse.org/reports

Hamer Christopher 1998. 'A Global Parliament: Principles of World Federation.' Sydney: Oyster Bay Books.

Harmel 1967. 'Report of the Council on the Future Tasks of the Alliance' (the Harmel Report), see https://www.nato.int/cps/en/natohq/topics_67927. $\underline{\mathrm{htm}}$

Jones James 2007. 'Stronger Political Structures for NATO', Freedom and Union 2, no.1: 10-11.

Juncker Jean-Claude 2016. We need a European army, 9 March, see http://www.bbc.com/news/worldeurope-31796337

Leinen Jo and Bummel Andreas 2018. A World Parliament: Governance and Democracy in the $21^{\text {st }}$ Century. Democracy Without Borders.

Maastricht 1992. Treaty on European Union, see http://eur-lex.europa.eu/legal-content/EN/

$\mathrm{TXT} /$ ?uri=uriserv\%3 $\mathrm{Axy} 0026$

McCain John 2007. McCain Remarks, Hoover Institution (speech, Stanford University, Stanford, CA, May 1). see http://media.hoover.org/sites/ default/files/documents/McCain 05-01-07.pdf.

Millard Everett Lee 1969. Freedom in a Federal World ( $5^{\text {th }}$ edition) p. 112. New York: Oceana.

Montreux Congress, 1947. See http://www.wfm-igp. org/our-movement/history, and Wittner L.S. 1993. One World or None. Stanford: Stanford University Press.

Morgenthau Hans 1973. Politics Among Nations $\left(5^{\text {th }}\right.$ edition). New York: Alfred A. Knopf.

Nathan Otto and Nordern Heinz 1968. Einstein on Peace, p. 336. New York: Schocken Books.

Naumann Klaus, Shalikashvili John, Inge The Lord, Lanxade Jacques and van den Breemen Henk 2007. 'Towards a Grand Strategy for an Uncertain World - Renewing Transatlantic Partnership', see http://www.voltairenet.org/IMG/pdf/NATO new $\underline{\text { Strategy-2.pdf }}$

Penn William 1692. Essay towards the Present and Future Peace of Europe. reprinted in Cook B.W. Cooper S.E. and Chatfield C. (eds.) 1972 Peace Projects of the Seventeenth Century New York: Garland.

Princeton Project 2006. Ikenberry G. John and Slaughter Ann-Marie, Co-Directors. Forging a World of Liberty under Law: U.S. National Security in the $21^{\text {st }}$ Century, Final Paper of the Princeton Project on National Security. see http://www2. world-governance.org/IMG/pdf_0080_Forging_a World of_Liberty_Under_Law.pdf

Sagan Carl 1994. Pale Blue Dot: A Vision of the Human Future in Space. Random House, New York

Schweickart Rusty 1977. 'No Frames, No Boundaries', in Earth's Answer. ed. M. Katz, et al., Harper and Row, New York; pp. 11-12.

Schuman Declaration, 1950. See https://europa.eu/ european-union/about-eu/symbols/europe-day/ schuman-declaration_en

Stevenson, Adlai 1965. Strengthening the International Development Institutions, a speech before the United Nations Economic and Social Council, Geneva, Switzerland, July 9, 1965.see: 
http://www.adlaitoday.org/articles/connect2 geneva 07-09-65.pdf

Stoltenberg Jens 2016. announcement June 13, see http://www.rferl.org/a/nato-baltics-poland-russiaukraine-battalions/27795258.html

Streit Clarence K. 1939. 'Union Now!' New York: Harper \& Brothers.

UNPA. Campaign for a United Nations Parliamentary Assembly, http://en.unpacampaign.org/

Warsaw Summit Communique 2016. see http://www. nato.int/cps/en/natohq/official texts 133169.htm

Wells, H.G. 1922. The Outline of History, Vol II, p.754 London: George Newnes.

WFM-IGP. The World Federalist Movement - Institute for Global Policy, see http://www.wfm-igp.org/

White, F. 2014. The Overview Effect: Space Exploration and Human Evolution. American Institute of Aeronautics and Astronautics, Reston. 
